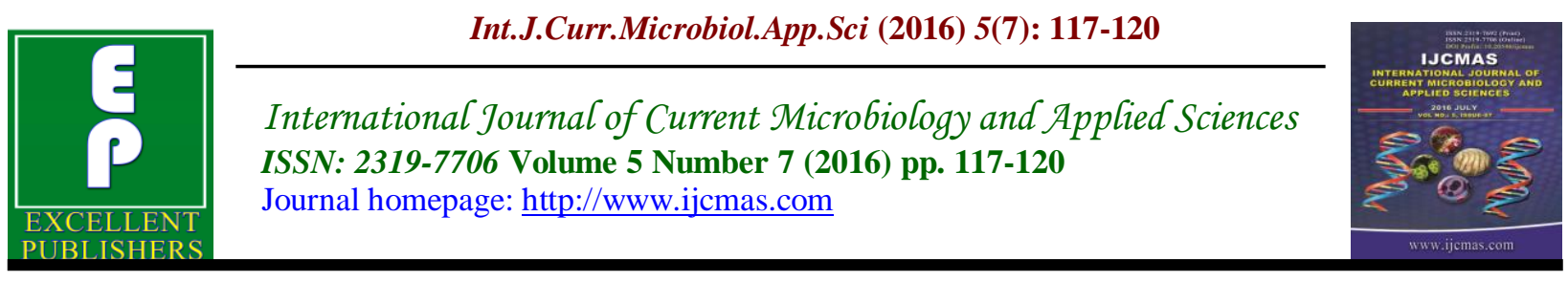

Original Research Article

http://dx.doi.org/10.20546/ijcmas.2016.507.009

\title{
Simultaneous Biosorption of Iron (II) and Zinc (II) onto Flyash from Aqueous Solutions
}

\author{
Ahmad Ashfaq* and Mohd Kaifiyan \\ Civil Engineering Section, Faculty of Engineering \& Technology, Aligarh Muslim \\ University, A.M.U., Aligarh, India \\ *Corresponding author
}

\begin{abstract}
A B S T R A C T
Keywords

Environment, Heavy metals, Flyash, Iorn(II) and Zinc(II) Biosorption.

\section{Article Info}

Accepted:

12 June 2016

Available Online:

10 July 2016

The release of large quantities of heavy metals into the natural environment has resulted in a number of environmental problems. The treatment technologies that have been used for treating heavy metal bearing waste streams, such as chemical precipitation, adsorption, ion-exchange, and solvent extraction, have been found to be limited, involve high capital and operational costs and may also be associated with the generation of secondary wastes that also present treatment problems biosorption of heavy metals offers a potential alternative to existing methods for detoxification and recovery of these components from industrial wastewaters and is a subject of extensive studies. The biosorption of Iron(II) and Zinc(II) both ions in combination, by flyash was studied in a batch system as a function of initial $\mathrm{pH}$ and dual-metal ion concentrations. The working $\mathrm{pH}$ values were determined to the selective uptake of metal ions. Multi component biosorption studies were performed at the initial $\mathrm{pH}$ values. It was observed that the biosorption kinetics and equilibrium uptakes of Iron(II) and Zinc(II) ions in binary mixtures changed due to the initial biosorption $\mathrm{pH}$ and the presence of the other component.
\end{abstract}

\section{Introduction}

Fly ash is the by-product of thermal power stations and is a waste material available in large quantities free of cost. Chemical and physical properties of fly ash differ according to the nature of the coal used in thermal power stations. Heavy metals like $\mathrm{Zn}, \mathrm{Pb}, \mathrm{Cd}, \mathrm{Ni}$ and $\mathrm{Cu}$ have been removed from municipal solid waste leachate by fly ash (Mohan, et al., 2009) of thermal power plant. The main techniques used to remove heavy metal ions from aqueous streams include ion-exchange chromatography, reverse-osmosis, chemical precipitation, and adsorption. Adsorption as a wastewater treatment process has aroused considerable interest during recent years. Adsorption has evolved as the front line of defense for metal ions, which cannot be removed by other techniques. The adsorption of metals by activated carbon is more complex than for organic compounds because the ionic charges affect their removal rates from solution. Metal ion adsorption by flyash varies with the chemical properties of adsorbate, temperature, $\mathrm{pH}$, ionic strength of the liquid phase, etc. Many activated 
carbons are available commercially but few are selective for heavy metals and they are expensive. Due to the expense of carbon for water treatment, a search for substitutes is under way. Wastewater treatments require vast quantities of activated carbon, so improved and tailor-made adsorbents are needed for these demanding applications. Such adsorbents should be easily available, economically feasible, and readily and quantitatively regenerated chemically (Kumar, et al., 2015). Much of the work on the adsorption of heavy metal ions by various kinds of adsorbents has focused on the uptake of single metals. Since industrial effluents can contain several metals, it is necessary to study the simultaneous sorption of two or more metals and also to quantify the interference of one metal with the sorption of the other. Thus the studies on equilibrium and kinetics of adsorption of heavy metals from binary systems are very important. Various single component equilibrium adsorption isotherm equations have been extended and modified for use in binary and multi-component systems. (Srivastava, et al., 2006, 2008). In this study, we report the investigation on the feasibility of coal fly ash to remove heavy metal ions [ $\mathrm{Zn}(\mathrm{II}), \mathrm{Fe}(\mathrm{II})]$ from water, modeling the adsorption process of heavy metal ions and investigation of the interactive effects of process parameters such as biosorbent dose, contact time, solution $\mathrm{pH}$, and initial concentration on the sorption capacity towards the metal ions.

\section{Materials and Methods}

\section{Metal Biosorption from Bimetallic}

Efforts have been made to find out the sorption behavior of the flyash exposed to bimetallic solution. Metal solution contained bimetallic in the concentration range of 10$100 \mathrm{mgl}^{-1}$ for each metal. Batch equilibrium sorption experiments were carried out using standard batch methodology. Samples were withdrawn at predetermined time intervals and the metal sorbed was determined by subtracting the metal left in the solution after $2.5 \mathrm{~h}$ of biosorption from the initial metal ion concentration. In order to determine sorption characteristics of Fe (II) in binary metal mixture, the initial concentration was varied from 10 to 100 $\mathrm{mg} / \mathrm{l}$ while the $\mathrm{Zn}$ concentration in each biosorption medium was held constant at 10 , 20, 50, $80 \& 100 \mathrm{mgl}^{-1}$. The $\mathrm{pH}$ of biosorption media was adjusted to the optimum value for the biosorption of $\mathrm{Zn}$ with $1 \mathrm{~N} \mathrm{HCl}$ and $1 \mathrm{~N} \mathrm{NaOH}$.

\section{Results and Discussion}

The simultaneous removal of $\mathrm{Zn}$ (II) and $\mathrm{Fe}$ (II) onto flyash was evaluated. In order to have the selectivity for $\mathrm{Zn}(\mathrm{II})$ ions, the $\mathrm{pH}$ of biosorption media was adjusted to 6.4 , which was considered as the optimum value for the biosorption of metal ions. In the first stage of biosorption studies, the initial $\mathrm{Zn}$ (II) concentration was varied from 10 to 100 $\mathrm{mg} / \mathrm{L}$, while the initial $\mathrm{Fe}(\mathrm{II})$ concentration was held constant at $10,20,50$ or $60 \mathrm{mg} / \mathrm{L}$. The non-linearized biosorption isotherms of $\mathrm{Zn}$ (II) ions in the absence of and in the presence of increasing concentrations of $\mathrm{Fe}$ (II) ions are shown in Fig: 1. It can be observed from the figures that the equilibrium $\mathrm{Zn}$ (II) uptake increased (3.16$31.92 \mathrm{mg} / \mathrm{g}$ ) by increasing the initial $\mathrm{Zn}$ (II) concentration up to $100 \mathrm{mg} / \mathrm{L}$. In addition, the presence and increasing $\mathrm{Fe}(\mathrm{II})$ concentration resulting in shortening of biosorbed $\mathrm{Fe}$ (II) (17.38 to $13.04 \mathrm{mg} / \mathrm{g}$ ) quantities, at equilibrium. The inhibitory effect of $\mathrm{Zn}$ (II) ions on the equilibrium Fe (II) uptakes was dominating. Although $\mathrm{Zn}$ (II) ions were preferentially biosorbed, Fe (II) ions were also biosorbed by the flyash. This situation shows the partial competition 
between the $\mathrm{Zn}(\mathrm{II})$ and $\mathrm{Fe}(\mathrm{II})$ ions. Under study sorption, isotherms of $\mathrm{Zn}$ (II) and $\mathrm{Fe}(\mathrm{II})$ in the presence of constant concentrations of other metal $(10,20,50 \&$ $60 \mathrm{mg} / \mathrm{g}$ ) were computed from the empirical Freundlich isotherm and the comparison between experimental and computed values are shown in Fig: 1. A good agreement for the experimental data with the empirical Freundlich model was obtained for the binary aqueous solution. In addition, the Freundlich model physically provides a more realistic description of metal biosorption by flyash because it accounts for different binding sites.

Fig.1 The empirical Freundlich biosorption isotherms of $\mathrm{Zn}(\mathrm{II})[\mathrm{pH}: 6.4]$ in the presence of increasing concentrations of Fe(II).
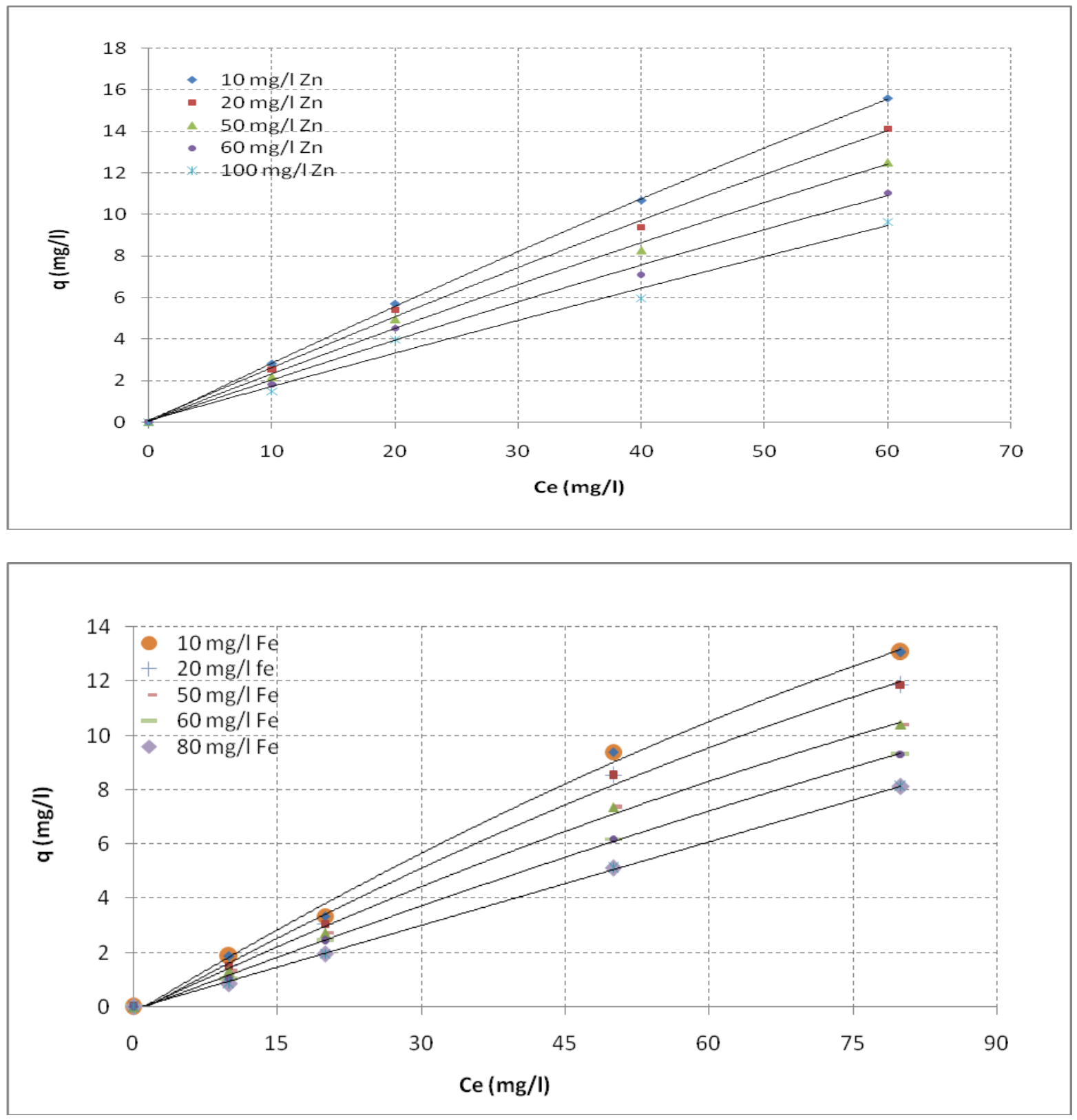
In conclusion, in this work, experiments were studied under laboratory conditions. From the experimental data of biosorption of $\mathrm{Fe}(\mathrm{II})$ and $\mathrm{Zn}(\mathrm{II})$ ions onto flyash, the following points can be concluded. The sorption capacity of metal ions was found dependent on initial $\mathrm{pH}$, contact time, sorbent amount and metal concentration of heavy metal. The obtained maximum sorption capacity of flyash for removal of selected heavy metals was $15.88 \mathrm{mg} / \mathrm{g}$ for $\mathrm{Fe}(\mathrm{II})$ and $12.74 \mathrm{mg} / \mathrm{g}$ for $\mathrm{Zn}(\mathrm{II})$.

\section{Acknowledgement}

This research was financially supported by the Council of Science \& Technology, Uttar Pradesh (C.S.T. U.P, Lucknow) with Project Gant No: C.S.T. / D.1440.

\section{References}

Mohan, S., Gandgandhimathi, R. 2009. Removal of heavy metal ions from municipal solid waste leachate using coal fly ash as an adsorbent. $J$. Hazardous, 169(1-3): 351-359.

Senthil kumar, G., Murugappan. 2015. A Multicomponent Adsorption Isotherm Studies on Removal of Multi Heavy Metal Ions in MSW Leachate using Flyash. IJERT, 4(08): 58-66.

Srivastava, V.C., I.D. Mall, Mishra. I.M. 2006. Modelling Individual and Competitive Adsorption of Cadmium(II) and Zinc(II) Metal Ions from Aqueous Solution onto Bagasse Fly Ash. Separation Sci. Technol., 41(12): 2685-2710.

Srivastava, V.C., I.D. Mall, Mishra. I.M. 2008. Removal of cadmium(II) and zinc(II) metal ions from binary aqueous solution by rice husk ash. Colloids and Surfaces A: Physicochem. Eng. Aspects, 312: 172184.

\section{How to cite this article:}

Ahmad Ashfaq and Mohd Kaifiyan. 2016. Simultaneous Biosorption of Iron (II) and Zinc (II) onto Flyash from Aqueous Solutions. Int.J.Curr.Microbiol.App.Sci. 5(7): 117-120. doi: http://dx.doi.org/10.20546/ijcmas.2016.507.009 